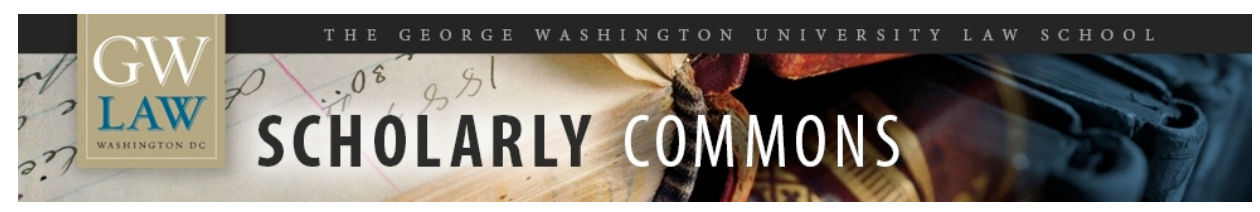

\title{
Strict Liability in International Environmental Law
}

Dinah L. Shelton

George Washington University Law School, dshelton@law.gwu.edu

Follow this and additional works at: https://scholarship.law.gwu.edu/faculty_publications

Part of the Law Commons

\section{Recommended Citation}

Dinah L. Shelton \& Alex Kiss, Strict Liability in International Environmental Law in LAW OF THE SEA, ENVIRONMENTAL LAW AND SETTLEMENT OF DISPUTES: LIBER AMICORUM JUDGE THOMAS A. MENSAH (Tafsir Malick Ndiaye and Rüdiger Wolfrum, eds., Brill Academic Publishers, 2007).

This Article is brought to you for free and open access by the Faculty Scholarship at Scholarly Commons. It has been accepted for inclusion in GW Law Faculty Publications \& Other Works by an authorized administrator of Scholarly Commons. For more information, please contact spagel@law.gwu.edu. 


\title{
STRICT LIABILITY IN INTERNATIONAL ENVIRONMENTAL LAW
}

\author{
Alexandre Kiss ${ }^{\dagger}$ and Dinah Shelton
}

\begin{abstract}
T The principle that a State is responsible for causing environmental harm outside its territory in breach of an international obligation has been slow to evolve to address the allocation of loss due to accidents. The issue was not before the arbitral tribunal in the well-known dispute between the United States and Canada ${ }^{1}$ concerning the activities of the Canadian smelter located in Trail, British Colombia. The arbitral tribunal asserted a general duty on the part of a State to protect other States from injurious acts by individuals within its jurisdiction. The arbitral agreement itself recognized the responsibility of a State for the acts of non-State actors as well as those of the State or its organs. Summing up, the tribunal found that "no State has the right to use or permit the use of its territory in such a manner as to cause injury by fumes in or to the territory of another or the properties or persons therein, when the case is of serious consequence and the injury is established by clear and convincing evidence". ${ }^{2}$

The tribunal noted difficulty of determining what constitutes an injurious act. Despite claims for absolute prohibition of harmful activities, the tribunal agreed with national court precedents that States should take reasonable precautions to prevent harm, the same as those it would take to protect its own inhabitants. It may be concluded that a State's failure to regulate or prevent serious harm from polluting activities, in instances where it would protect its own inhabitants, would constitute a wrongful act.

The Trail Smelter arbitration set the foundations for discussions of responsibility and liability in environmental law ${ }^{3}$ but it left open the question of whether a State exercising all due diligence would be liable if transfrontier harm results despite the State's best efforts. More generally, the tribunal did not clarify whether a State is liable only for intentional, reckless or negligent behavior (fault based
\end{abstract}

\footnotetext{
1 1931-1941, 3 RIAA 1905.

23 RIAA 1938, 1965.

3 The case continues to be invoked. In 1972, Canada referred to the judgment when an oil spill in Washington polluted beaches in British Colombia. 11 CYIL 333-334 (1973).
}

Ndiaye and Wolfrum (eds), Liber Amicorum Judge Thomas A. Mensah, 1131-1151

(C) 2007 Koninklijke Brill NV. ISBN 978900416156 6. Printed in the Netherlands. 
conduct) or whether it is strictly liable for all serious or significant transboundary environmental harm. In subsequent developments, international environmental law has come to distinguish responsibility, which arises upon breach of an international obligation, and liability for the injurious consequences of lawful activities. Progress towards clarification on this subject remains slow, however, as the following discussion demonstrates. ${ }^{4}$

\section{State Responsibility}

Following the Trail Smelter arbitration, the ICJ asserted a general duty to avoid transboundary injury in the 1949 Corfu Channel case, which referred to "every State's obligation not to allow knowingly its territory to be used contrary to the rights of other States". ${ }^{5}$ The same year as this decision, the United Nations Survey of International Law concluded that there is "general recognition of the rule that a State must not permit the use of its territory for purposes injurious to the interests of other States in a manner contrary to international law" ${ }^{6}$

Principle 21 of the 1972 Stockholm Declaration restated the norm formulated in the Trail Smelter arbitration and other cases as follows:

"States have, in accordance with the Charter of the United Nations and the principles of international law ... the responsibility to ensure that activities within their jurisdiction or control do not cause damage to the environment of other States or of areas beyond the limits of national jurisdiction."

The rule was reiterated in Principle 2 of the 1992 Rio Declaration and was again confirmed in the 2002 World Summit on Sustainable Development. It has also been reaffirmed in declarations adopted by the United Nations, including the Charter of Economic Rights and Duties of States and the World Charter for Nature, and has been adopted by other international organizations and conferences. ${ }^{7}$

4 On these topics, see T. Scovazzi, "State Responsibility for Environmental Harm", 12 YB Int'l Envtl. L. 43 (2001); J.G. Lammers, "International Responsibility and Liability for Damage Caused by Environmental Interferences”, 31 Envtl. Pol'y E L. 42 (2001); R. Bratspies \& R. Miller (eds), Transboundary Harm in International Law; Lessons from the Trail Smelter Arbitration (2006); G. Handl, "Transboundary Impacts”, in D. Bodansky, J. Brunnée \& E. Hey (eds), Oxford Handbook of International Environmental Law (2007); A. Boyle, "State Responsibility and International Liability For Injurious Consequences of Acts Not Prohibited By International Law: A Necessary Distinction”, 39 ICLQ 1 (1990).

5 ICJ Reports 1949, p. 22.

6 UN Doc. A/CN.4/1/Rev.1, at 34 (1949).

7 See e.g., Preliminary Declaration of a Program of Action of the European Communities in respect to the Environment, OJEC C 112/1, 20 December 1973; Final Act, Conference 
Its content is inserted in the Convention on the Law of the Sea ${ }^{8}$ as well as in art. 20 of the ASEAN Convention on the Conservation of Nature and Natural Resources. ${ }^{9}$ The 1979 Geneva Convention on Long Range Transboundary Air Pollution reproduces Principle 21 stating that the Principle "expresses the common conviction that States have" on this matter.

Principle 2 of the Rio Declaration appears in the preamble of the 1992 UN Framework Convention on Climate Change and article 3 of the Convention on Biological Diversity. Finally, the International Court of Justice recognized in an advisory opinion that " $[t]$ he existence of the general obligation of states to ensure that activities within their jurisdiction and control respect the environment of other states or of areas beyond national control is now part of the corpus of international law relating to the environment" ${ }^{10}$ This statement was repeated in the judgment concerning the Gabčíkovo-Nagymaros Project, in which the Court also "recall[ed] that it has recently had occasion to stress ... the great significance that it attaches to respect for the environment, not only for states but also for the whole of mankind". ${ }^{11}$

While Stockholm Principle 21 and similar formulations can be read to impose absolute State responsibility for any transfrontier harm, whether intentional or accidental, States generally have not invoked it to assert claims for accidental harm, however damaging the impact. The Chernobyl incident is a case in point. ${ }^{12}$ Following the 26 April 1986 explosion in reactor Number 4 of the Chernobyl nuclear power plant, the resulting fire melted a portion of the uranium fuel. Although there was no nuclear explosion and the core of the reactor did not melt, the fire which engulfed the reactor was serious and released a large quantity of radioactive material into the air.

Large amounts of fallout occurred near the plant and spread beyond. Between 27 April and 8 May, nearly 50,000 persons were evacuated from towns located within a 30 kilometer radius of the plant. Two persons were immediately killed by the explosion, 29 died shortly after, and hundreds were afflicted with radiation poisoning. The foreign consequences were also severe, even though no deaths were immediately attributed to the accident. Following rapid changes in the

on Security and Cooperation in Europe, Helsinki, August 1976.

8 United Nations Convention on the Law of the Sea, art. 194(2).

9 ASEAN Agreement on the Conservation of Nature and Natural Resources (Kuala Lumpur, 9 July 1985), 15 Envtl. Pol'y \& L. 64 (1985).

10 Legality of the Threat or Use of Nuclear Weapons, Advisory Opinion, ICJ Reports 1996, pp. 241-242, para. 29.

11 Gabčíkovo-Nagymaros Project, Judgment, ICJ Reports 1997, p. 41, para. 53.

12 See L. Malone, "The Chernobyl Accident: A Case Study in International Law Regulating State Responsibility for Transboundary Nuclear Pollution", 12 Colum. J. Envtl. L. 203, 222 (1987). 
wind direction, the radioactive cloud which had formed crossed the airspace of a series of countries beginning with those of Scandinavia. Four days after the incident, radiation measurements along the Swedish coast were ten times higher than normal. The radioactive cloud moved south, crossing Germany, Austria, Switzerland, Yugoslavia and Italy.

No conventional international regulation applied at the time the accident occurred in the Soviet Union. The interpretation then given to the Convention on Long-Range Transboundary Air Pollution ${ }^{13}$ excluded pollution by radioactive elements. The USSR was not a contracting party to the Vienna Convention on Civil Liability for Nuclear Damage. ${ }^{14}$ Indeed, among the States that suffered effects from the radioactive cloud, only Yugoslavia had signed and ratified the Convention. There remained, therefore, only the recourse to general rules of international environmental law and after consideration none of the affected States presented a claim to the Soviet Union.

States did request the Governing Council of the IAEA to convene an extraordinary session with a group of governmental experts in order to elaborate measures to reinforce international cooperation in the field of nuclear security and radioactive protection. This meeting took place in Vienna from 21 July to 15 August 1986, and drafted two conventions which were adopted one month later by the IAEA General Conference. The Convention on Early Notification of a Nuclear Accident, signed 26 September, entered into force on 27 October; the Convention on Assistance in the Case of a Nuclear Accident or Radiological Emergency was signed the same day and also rapidly ratified by the signatories.

The instrument on assistance traces a general framework for cooperation between States on the one hand, and between the States and the IAEA on the other, in the case of nuclear accident or other radiological emergency. It seems that the last term can be interpreted as covering any danger caused by radiation, whatever the cause, and includes nuclear arms testing. Had the Convention on Assistance existed at the time of Chernobyl, any State exposed to radiation could have claimed assistance, whether or not the origin of the accident or emergency was found within its territory, under its jurisdiction or under its control. ${ }^{15}$ It is clear, however, that States parties did not accept any obligation other than cooperating among themselves and with the Agency in order to facilitate early response. ${ }^{16}$

Apparently no government pushed to conclude rules on State liability for accidental environmental harm. Negotiations would no doubt have been lengthy and perhaps unsuccessful over such matters as proximate harm, and

\footnotetext{
Geneva, 13 November 1979.

21 May 1963.

15 Art. 2, para. 1.

16 Art. 1, para. 1.
} 
mitigation of damages. The difficulty of evaluating the cost of the consequences of the Chernobyl accident, especially the precautionary measures taken by the affected countries, also may have been a determinant factor in avoiding the issue of State responsibility. It also seems, however, to be consistent with the general reticence displayed towards rules imposing strict liability on States for damages caused by that State or its citizens. The emphatic preference remains measures of prevention rather than cure.

Finally, in August 2001, the International Law Commission completed its Draft Articles on the Responsibility of States for Internationally Wrongful Acts, which the UN General Assembly "took note of" in Resolution 56/83 (December 2001). ${ }^{17}$ According to article 2 of the Draft Articles of the International Law Commission, there is an internationally wrongful act of a State when conduct consisting of an action or omission constitutes a breach of an international obligation of the State. Article 3 adds that the characterization of an act of a State as internationally wrongful is governed by international law. In other words the primary rules of conduct for States, i.e. their rights and duties, establish whether an act or omission constitutes a wrongful act. At present, as discussed in the next section, only a handful of treaties make States strictly liable for any harm that occurs in another State's territory as a result of specific activities, even if the State has otherwise complied with its legal obligations. The large majority of multilateral environmental treaties focus not on the harm to the injured State, but on the conduct of the acting State, imposing duties of comportment and of result.

\section{Strict Liability of States in Environmental Agreements}

Strict liability is foreseen in texts regulating activities considered as especially new or dangerous, such as the exploration and exploitation of the outer space, and which are largely conducted by State actors. The Convention on Principles Governing the Activities of States in the Exploration and Use of Outer Space, including the Moon and other Celestial Bodies, ${ }^{18}$ provides both for State responsibility and strict liability. First, article VI provides that the States Parties bear international responsibility for national activities in outer space, including the moon and other celestial bodies, whether such activities are carried on by governmental agencies or by non-governmental entities. The activities of nongovernmental entities in outer space, including the moon and other celestial

17 The General Assembly recommended the articles to the attention of Member States "without prejudice to the question of their final adoption or other appropriate action".

1827 January 1967, International Environmental Law, Multilateral Treaties (EMUT) 967:07. 
bodies, require authorization and continuing supervision by the appropriate State, thus ensuring State involvement. Article VII adds that each State that launches or procures the launching of an object into space and each State from whose territory or facility an object is launched, is liable to another State or to its natural or juridical persons for harm caused by such object, or its component parts, on the Earth, in air space or in outer space, including the moon and other celestial bodies. Taken together, these two provisions distinguish between responsibility based on fault (art. VI) and strict liability for the injurious consequences of space activities (art. VII).

The Convention on International Liability for Damage Caused by Space Objects ${ }^{19}$ develops these principles and gives several details concerning their implementation. According to its article II, a launching State is absolutely liable to pay compensation for damage caused by its space object on the surface of the earth or to aircraft in flight. Whenever two or more States jointly launch a space object, are jointly and severally responsible for any damage caused. A State from whose territory or facility a space object is launched shall be regarded as a participant in a joint launching. Exoneration from strict liability is granted to the extent that a launching State establishes that the damage has resulted from another's gross negligence or from an intentional act or omission. No exoneration will be granted in cases where the damage has resulted from activities conducted by a launching State in breach of international law. Nationals of the launching State or foreign nationals participating in the launching cannot ask for compensation of the damage caused by the launching State (art. VII).

A UN General Assembly resolution which proclaims several Principles Relevant to the Use of Nuclear Power Sources in Outer Space ${ }^{20}$ refers to the Space Treaty and the Convention on International Liability for Damage Caused by Space Objects:

"Each State which launches or procures the launching of a space object and each State from whose territory or facility a space object is launched is internationally liable for damage caused by such space objects or their component parts. This fully applies to the case of such a space object carrying a nuclear power source on board. Whenever two or more States jointly launch such an object, they shall be jointly and severally liable for any damage caused, in accordance with article $V$ of the above-mentioned Convention."

Such provisions establish a regime of strict liability and not of responsibility. Within the Antarctic system, efforts to conclude a liability annex to the 1991 Madrid Protocol partially succeeded in June 2005, with conclusion of a limited

1929 March 1972, EMUT, 972:24.

20 UNGA Res. A/47/68, 23 February1993 (32 ILM, 921). 
agreement on environmental emergencies, defined as any accidental event that takes place after the entry into force of the Annex when the accident results in or imminently threatens significant and harmful impact on the Antarctic environment. The agreement, adopted as Annex VI to the Protocol on Environmental Protection, will enter into force once all the present Consultative Parties have ratified it.

The scope of potential liability extends to all governmental and non-governmental activities for which advance notice is required under the Treaty, including tourism. The system is thus a "mixed" one of liability for operators whether they are governmental or non-governmental actors. This is significant because many activities in Antarctica are conducted or sponsored by governments. Each State party is to require its operators to undertake reasonable preventive measures, establish contingency plans for responses to incidents with potential adverse environmental impacts, and take prompt and effective responsive action when an emergency results from its activities. If the operator fails to take response action, the relevant party is "encouraged" to take such action, as are other parties after notifying the party of the operator, if such notification is feasible. Any operator that fails to take prompt and effective response action is liable to pay the costs of response action taken by parties. Where the defaulting operator is a State operator and no party took response action, the State operator is liable to pay the equivalent of the costs of response action that should have been taken. This sum is paid into a fund. ${ }^{21}$

Liability is strict, but an operator will not be liable if the operator proves that the emergency was caused by (1) an act or omission necessary to protect human life or safety; (2) an exceptional natural disaster which could not have been reasonably foreseen, provided all reasonable preventive measures have been taken; (3) an act of terrorism; or (4) an act of belligerency against the activities of the operator. Sovereign immunity for warships is maintained, limits on liability are provided, and operators are to be required by each party to maintain adequate insurance or other financial security.

Residual State liability is also included in the Annex. Although article 10 is drafted in the negative, to assume no liability, it nonetheless sets forth circumstances in which a party will be held liable:

"A Party shall not be liable for the failure of an operator, other than its State operators, to take response action to the extent that the Party took appropriate measures within its competence, including the adoption of

21 Article 12 of the Liability Annex mandates the Secretariat of the Antarctic Treaty to maintain and administer a fund for the reimbursement of the reasonable and justified costs incurred by a party or parties in taking response actions to environmental emergencies. 
laws and regulations, administrative actions and enforcement measures, to ensure compliance with this Annex."

Although this article refers to liability, it seems to discuss State responsibility instead, because its focus is a State's failure to comply with its legal obligations to take appropriate measures to prevent harm by non-State actors within its jurisdiction. Such omissions are often the basis of claims against States under the law of State responsibility.

\section{The Development of Norms on State Liability for Hazardous Lawful Activities}

Since 1978, the International Law Commission has considered the question of "international liability for injurious consequences arising out of acts not prohibited by international law". In 1997, the ILC decided to deal only with the question of prevention of transboundary damage from hazardous activities and within four years it was able to present to the UN General Assembly a completed set of 19 articles on this topic. ${ }^{22}$ The General Assembly reviewed the articles and, pressed by certain member States, asked the ILC to continue working on the topic of international liability, "bearing in mind the interrelationship between prevention and liability...”. ${ }^{23}$ By July 2004 a draft set of principles on Allocation of Loss in the Case of Transboundary Harm Arising Out of Hazardous Activities was provisionally adopted by the Commission on first reading, ${ }^{24}$ and after comments by States, adopted on second reading in May $2006 .{ }^{25}$ To a large extent, these efforts can be seen to supplement and complete the ILC articles on Responsibility of States for Internationally Wrongful Conduct, ${ }^{26}$ although the content of the adopted rules appears largely to repudiate State liability when the State has complied with the Draft Articles on Prevention.

22 See Draft Articles on Prevention of Transboundary Harm from Hazardous Activities, in Report of the International Law Commission on the Work of its Fifty-Third Session, UN GAOR, 56th Sess. Supp. No. 10, UN Doc. A/56/10, 370 (2001).

23 UN Doc. A/Res/56/82 of 18 January 2002.

24 UN Doc. A/59/10, 153-156.

25 See Draft Report of the International Law Commission on the Work of its Fifty-Eighth Session, Chapter V: International Liability for Injurious Consequences Arising out of Acts not Prohibited by International Law (International Liability in Case of Loss from Transboundary Harm Arising out of Hazardous Activities), UN Doc. A/CN.4/L.693/ Add.1, 9 June 2006.

26 Report of the International Law Commission on the Work of its Fifty-Third Session, UN GAOR, 55th Sess. Supp. No. 10, UN Doc. A/56/10 (2001). 
The draft principles correctly approach the issue as one of allocating the risk of loss due to harm resulting from lawful economic or other activities, when the relevant State has complied with its due diligence obligations to prevent transboundary harm. The articles have merit in providing a general framework for States to adopt domestic law or conclude international agreements to ensure prompt and adequate compensation for the victims of transboundary damage caused by lawful hazardous activities. It is also explicitly stated that an additional purpose of the draft principles is "to preserve and protect the environment in the event of transboundary damage, especially with respect to mitigation of damage to the environment and its restoration and reinstatement". This progressive principle should be read in the light of the broad definitions of damage, ${ }^{27}$ environment $^{28}$ and hazardous activity ${ }^{29}$ set forth in Principle 2. The last definition in particular extends strict liability considerably beyond that provided in most domestic law. While there is an important restriction in the exclusion of harm to the commons from the scope of these principles, on the whole they give a prominent place to the protection and preservation of the environment per se for the benefit of present and future generations.

The draft principles support existing State practice, described in the following section, which largely channels liability to the owner or operator and demands financial guarantees against future harm. As with many existing environmental treaties, the Principles call for imposing strict liability on the operator or other person or entity and requiring financial security to cover claims of compensation. In appropriate cases, industry-wide funds should be established at the national level.

The articles do not support strict liability between States, unless the State itself is the operator. ${ }^{30}$ Principle 4(5) provides only that in the event that the measures for operator liability are insufficient, "the State of origin should also ensure that additional financial resources are made available". Other obligations are placed on the State, however. It must promptly notify all States that are potentially or actually affected, ensure that appropriate response measures

27 In addition to personal and property losses, damage includes "loss or damage by impairment of the environment, the costs of reasonable measures of reinstatement of the environment, including natural resources, and the costs of reasonable response measures" (Principle 2(1)(iii-v)).

28 Environment includes natural resources, both abiotic and biotic, such as air, water, soil, fauna and flora and the interaction between the same factors, and the characteristic aspects of the landscape (Principle 2(b)).

29 In probably the broadest definition given in the draft articles, a hazardous activity "means an activity which involves a risk of causing significant harm" (Principle 2(c)).

30 The Commentary to the Draft Principles expressly States that "[i]t is envisaged that a State could be an operator for purposes of the present definition". UN Doc. A/CN.4/L.693/ Add.1, 41, para. 33. 
are taken, and provide domestic remedies. Other measures are recommended, including consultation on measures of mitigation, seeking the assistance of competent international organizations, and providing appropriate access to information on remedies. In addition, States may negotiate specific agreements on the topic of strict liability.

The lack of any serious consideration of State liability may be understood in the context of the prior articles on prevention: failure to fulfill the due diligence duty to prevent is considered to breach an international obligation and shifts the applicable legal regime to one of State responsibility. Still, to dismiss liability as "a case of misplaced priority" 31 ignores existing positive law which, as described above, has accepted the principle of State liability without fault in a series of treaties concerning ultrahazardous activities that are largely conducted by State actors.

These are clearly circumstances in which the primary obligation of a State is to ensure/insure that harm does not occur. Nonetheless, the ILC appears to have decided that strict liability of States does not even have support as a measure of progressive development in the law. ${ }^{32}$ Instead, the ILC limits itself to noting that certain categories of hazardous activities might be included in treaties providing for State-funded compensation schemes to supplement civil liability. It stops well short of finding that such compensation is legally required.

Strict liability of States thus remains very controversial and the preference is clearly in favor of imposing civil liability on operators. Those subject matters for which State liability has been accepted in practice uphold this preference because they largely concern activities typically undertaken by government actors, at least until recently: e.g. outer space exploration and exploitation and Antarctic scientific research. States seem willing to accept liability for their own conduct, but not for that of private actors.

\section{Strict Liability of Non-State Actors}

Treaties related to environmental protection include clauses establishing strict liability of individuals. In interstate relations such liability is linked with specified activities, considered as potentially damaging for the environment. Current treaties on civil liability number about one dozen, nearly all of them concerned with a single hazardous activity (e.g. nuclear energy or oil transport). Several conventions address vessel-source marine pollution or nuclear damage, while

31 P.S. Rao, First Report on the Legal Regime for Allocation of Loss in Case of Transboundary Harm Arising out of Hazardous Activities, UN Doc. A/CN.4/531 (2003), 7.

32 P.S. Rao, Third Report on the Legal Regime for Allocation of Loss in Case of Transboundary Harm Arising out of Hazardous Activities, UN Doc. A/CN.4/566 (2006), para. 31. 
pollution from offshore oil and gas exploitation, carriage of dangerous goods by various means of transport, and transboundary movements of hazardous wastes are each regulated by a single treaty.

Three nuclear liability treaties adopted in the 1960s aim partly to protect potential victims and partly to insulate nuclear industry from devastating claims. The 1960 Convention on Third Party Liability in the Field of Nuclear Energy (Paris Convention) ${ }^{33}$ was concluded in the context of OECD. It was intended to provide unified rules for adequate and equitable compensation while still supporting development of nuclear energy. The Paris Convention has not been widely ratified, nor have other agreements in this field been broadly accepted. There are no known transnational claims brought to date based on the Paris Convention, although some national claims ${ }^{34}$ have been based on legislation implementing the Paris Convention. The Paris Convention was later enhanced in 1963 with a Supplementary Convention (Brussels). ${ }^{35}$ Protocols amending the Paris Convention and the Brussels Supplementary Convention were adopted in February $2004,{ }^{36}$ broadening the concept of nuclear damage and the geographic scope of the Convention. However, environmental damage on the high seas or deep seabed remains excluded.

The Paris Convention became linked to a 1963 Vienna Convention on Civil Liability for Nuclear Damage ${ }^{37}$ by a Joint Protocol adopted in 1988 and by the 1997 Protocol of Amendment. ${ }^{38}$ The 1997 Amended Vienna Convention provides that it in principle applies to nuclear damage wherever suffered, with limited exclusions. These conventions take the same approach to liability:

- Liability is channeled exclusively to the operators of the nuclear installations;

- Liability of the operator is strict, i.e. the operator is held liable irrespective of fault;

335 AJIL 1082 (1961).

34 E.g. Merliun v. British Nuclear Fuels, (1990) 3 All ER 711.

35 The Supplementary Convention allows compensation beyond the liability limits of the Paris Convention. All claims must be brought in the State where the incident occurred if there is one and if not then the territory of the installation or the operator liable. Claims must normally be brought within ten years of the date of the incident and awards are enforceable in any State party. Eleven States are parties to the Supplementary Convention.

36 Protocol of 12 Feb. 2004 amending the 1960 Paris Convention; Protocol of 12 Feb. 2004 amending the 1963 Brussels Supplementary Convention.

372 ILM 727 (1963).

3836 ILM 1462 (1997). 
- The amount of liability is limited, although the limits may be raised or removed if fault is shown; ${ }^{39}$

- Liability is limited in time; ${ }^{40}$

- The operator must maintain insurance or other financial security for an amount corresponding to his liability; if such security is insufficient, the installation State is obliged to make up the difference up to the limit of the operator's liability;

- Jurisdiction over actions lies exclusively with the courts of the Contracting Party in whose territory the nuclear incident occurred; and

- A guarantee of non-discrimination of victims on the grounds of nationality, domicile or residence is provided.

In 1988, as a result of efforts by the IAEA and OECD/NEA, a new Joint Protocol Relating to the Application of the Vienna Convention and the Paris Convention combined them into one expanded liability regime. Parties to the Joint Protocol are treated as though they were Parties to both Conventions and a choice of law rule determines which of the two Conventions should apply to the exclusion of the other in respect of the same incident.

The 1997 Protocol $^{41}$ sets the possible limit of the operator's liability for a single nuclear incident at not less than 300 million Special Drawing Rights (SDRs) (equivalent to USD 400 million). The Amended Paris Convention changed the unit of account to the euro and more than doubled the minimum amount to at least 700 million euro. The 1997 Protocol also redefined nuclear damage to include the concept of environmental damage and preventive measures, extended the geographical scope of the Vienna Convention, and extended the

39 The Vienna Convention does not fix an upper ceiling for compensation, while the Paris Convention sets a maximum liability of 15 million Special Drawing Rights (SDRs). The Brussels Supplementary Convention established additional funding beyond the amount available under the Paris Convention up to a total of 300 million SDRs, consisting of contributions by the installation State and contracting parties.

40 Originally, compensation rights were extinguished under the Paris and Vienna Conventions if an action was not brought within ten years from the date of the nuclear incident. Longer periods were permissible if, under the law of the installation State, the liability of the operator is covered by financial security. National law may establish a shorter time limit, but not less than two years (the Paris Convention) or three years (the Vienna Convention) from the date the claimant knew or ought to have known of the damage and the operator liable. The Amended Conventions extend the statute of limitations with respect to loss of life or personal injury from ten to thirty years.

41 Two instruments were in fact signed: the Protocol to Amend the Vienna Convention, 36 ILM 1462 (1997) and a Convention on Supplementary Compensation for Nuclear Damage, 36 ILM 1473 (1997). 
period during which claims may be brought for loss of life and personal injury. It also provides for jurisdiction of coastal States over actions incurring nuclear damage during maritime transport. In addition, a 1971 Convention relating to Civil Liability in the Field of Maritime Carriage of Nuclear Material ${ }^{42}$ provided for shipowner liability if the shipowner committed or omitted an act with intent to cause damage.

Even more than nuclear operations, environmental injury caused by marine oil pollution is regulated by an entire system based on the 1969 International Convention on Civil Liability for Oil Pollution as modified in 1971, 1976, 1984 and $1992^{43}$ together with the 1971 Convention on the Establishment of an International Fund for Compensation for Oil Pollution Damage, also modified by protocols, the latest being adopted in 2003. ${ }^{44}$ The 1969 Convention established the liability of the owner of a ship ${ }^{45}$ for pollution damage caused by oil escaping from the ship as a result of an incident on the territory of a party. Other marine liability conventions include the 1976 International Convention on Civil Liability for Oil Pollution Damage Resulting from the Exploration for or Exploitation of Seabed Mineral Resources, ${ }^{46}$ the 1996 International Convention on Liability and Compensation for Damage in Connection with the Carriage of Hazardous and Noxious Substances by Sea (HNS Convention), ${ }^{47}$ and the 2001 International Convention on Civil Liability for Bunker Oil Pollution Damage. ${ }^{48}$

$42 \quad 11$ ILM 277 (1972).

43 In contrast to the treaty system, some States, notably the US, have enacted national legislation with much higher limits of liability, including some contexts in which liability is unlimited. See Oil Pollution Act of 1990, Public Law 101-380, enacted following the Exxon Valdez disaster of 1989.

44 IMO Doc. 92 FUNA/A.8/4.

45 The owner of the ship is not responsible if he can prove that the damage resulted from an act of war, hostilities, civil war, insurrection or a natural phenomenon of an exceptional, inevitable and irresistible character. The same is true if the damage results from an act or omission of a third party done with intent to cause damage or results from the negligence or other wrongful act of any government or other authority responsible for the maintenance of lights or other navigational aids.

4617 December 1976, 16 ILM 1451 (1977).

473 May 1996, 35 ILM 1415 (1996); IMO Doc. LEG/CONF.10/8/2 (9 May 1996). The HNS treaty system of liability is similar to the 1992 oil pollution agreement, imposing strict liability for damage caused. It has a wide definition of hazardous and noxious substances, excluding nuclear materials. Insurance is required and liability is limited on a sliding scale depending on the size of the ship. A second tier of compensation applies when shipowner not liable because the incident falls within the treaty's exceptions or the owner has no reason to know of the nature of the substances being transported, or where the claim exceeds the liability limits. A fund is created, financed by levies on the importation of HNS cargoes.

4823 March 2001, IMO Doc. LEG/CONF.12/DC/1. 
The Oil Pollution Convention defines pollution as "loss or damage caused outside the ship carrying oil by contamination resulting from the escape or discharge of oil from the ship, wherever such escape or discharge may occur, and includes the cost of preventive measures and further loss or damage caused by preventive measures". While the 1969 Convention applied to incidents wherever occurring, article 3 of the 1992 Protocol specified that the Convention covers only damage suffered in the territory, the territorial sea or the EEZ of a Contracting State. The Convention also applies to preventive measures, wherever taken, to prevent or minimize such damage, including environmental damage. It states, however, that compensation for impairment of the environment other than loss of profit from such impairment shall be limited to costs of reasonable measures of reinstatement actually undertaken or to be undertaken..$^{49}$ The owner may limit liability except in case of actual fault and must maintain insurance or other financial security to cover its liability.

Strict liability for maritime pollution was extended to other hazardous substances in 1996 with the adoption of the HNS Convention. ${ }^{50}$ The Convention covers claims for damage arising from the carriage of such substances at sea, i.e. that period during which the substances are on the ship or ship's equipment. Article 1(6) of the HNS Convention defines damage to include, in addition to loss of life or personal injury or the loss of or damage to property, loss or damage by contamination of the environment caused by hazardous and noxious substances, provided that compensation for impairment of the environment other than loss of profit from such impairment shall be limited to the costs of reasonable measures of reinstatement actually undertaken or to be undertaken, and the costs of preventive measures and further loss or damage caused by preventive measures.

The marine pollution system balances strict liability with limits on liability. The Protocol of 1996 to amend the Convention on Limitation of Liability for

49 Art. 8(2) of the Antarctic Mineral Resource Activities Convention which never entered into force also provided for strict liability for damages "in the event that there has been no restoration to the status quo ante". The Council of Europe rules on compensation for damage caused to the environment include among the definitions given in article 2(9): “'Measures of reinstatement' means any appropriate and reasonable measures aiming to reinstate or restore damaged or destroyed natural resources or where appropriate or reasonable to introduce the equivalent of these resources into the environment." In all cases, restoring the environment to its status quo ante is the preferred remedy and this is especially true where it is difficult to assess the harm and the corresponding compensation. Only when restoration is not possible would it then be necessary to measure the damages.

50 For a similar strict liability regime, see the earlier Convention on Civil Liability for Damage Caused during Carriage of Dangerous Goods by Road, Rail and Inland Navigation Vessels of 10 October 1989. 
Maritime Claims of 19 November $1976,{ }^{51}$ established a ceiling defined by IMF special withdrawal rights. ${ }^{52}$ The Protocol differentiates between types of claims. Claims for loss of life or personal injury have a minimum limit of two million Units of Account, a limit which increases with the tonnage of the involved ship. In respect of any other claim the minimum is one million units which is augmented following the same method. For States which are not members of the IMF the corresponding amounts are respectively 30 million and 15 million monetary units (art. 8(2)).

A claim of compensation for pollution damage may be brought directly against the insurer or other persons providing financial security for the owner's liability for pollution damage. In order to benefit from the limitation on liability, the owner must deposit the sum representing the limit of his liability with the court or other authority with jurisdiction. If liability is found, the fund is then distributed among the claimants in proportion to their established claims. ${ }^{53}$ The owner of a ship registered in a contracting State and carrying more than 2,000 tons of oil in bulk as cargo must maintain insurance or other financial guarantee of compensation in case of liability for pollution damage. An insurance or guarantee certificate must be issued to each ship by the appropriate national authority and contracting States are obliged to prevent a ship from trading unless the appropriate certificate has been issued. Each State must recognize the certificates issued by other contracting States.

The 1971 International Convention on the Establishment of an International fund for Compensation for Oil Pollution Damage, as modified, aims to assure payment of compensation for pollution damage to the extent that protection afforded by the Liability Convention proves insufficient. The Fund is required to pay compensation to any person suffering pollution damage if the person is unable to obtain full and adequate compensation for the damage under the terms of the Liability Convention, either because no liability arises under the treaty, because the owner is financially incapable of payment, or because the damage exceeds the owner's liability under the Convention. However, the total amount of damages that the Fund will pay is also limited, to 135 million Special Drawing Rights (SDR). This ceiling can be raised to 200 million for certain polluting accidents. ${ }^{54}$ Contributions to the Fund are made by any person who has received total quantities of oil in excess of 150,000 tons during the prior calendar year. ${ }^{55}$

\footnotetext{
2 May 1996, IMO Doc. LEG/CONF.10/8 (9 May 1996).

2 Protocol art. 2(2).

Arts 5(3) and 5(4).

54 Art. 4(4)(c).

55 Art. 10.
} 
The system has been active. Between 1971 and 2000, the Fund paid out nearly 300 million British pounds sterling with respect to 102 incidents. ${ }^{56}$ The system also continues to evolve. As a result of the marine disasters concerning the Nakhodka in 1997 and the Erika in 1999, the 2004 Protocol established a new international body, the International Oil Pollution Compensation Supplementary Fund, and created an optional third tier above those provided by the Civil Liability Convention and the Fund Convention. The Supplementary Fund, to be financed by oil receivers, will increase the aggregate available amount to 750 million SDR for any one incident.

The 2001 International Convention on Civil Liability for Bunker Oil Pollution Damage addresses the category of vessels responsible for the majority of oil spills. In contrast to earlier conventions dealing with damage caused by the cargo of relatively small and well-defined categories of vessels, the Bunker Convention potentially applies to all ships, defined as "any seagoing vessel and seaborne craft whatsoever". Bunker oil means "any hydrocarbon mineral oil, including lubricating oil, used or intended to be used for the operation or propulsion of the ship, and any residues of such oil". The definition of "pollution damage" is identical to that of the 1992 Convention on Civil Liability. It is also subject to the same limitation in that it does not cover damage to the environment in itself, but only clean-up costs and the loss of profit suffered by victims such as fishermen and local industries dependant on ocean resources and the tourist trade. Actions for compensation may only be brought in the courts of the States where damage was suffered. Ships must carry certificates attesting to their financial security and claims for compensation may be made directly against the insurer or other provider of financial security.

Unlike other treaties, the Bunker Oil Convention does not channel liability to a single person but defines ship owner to include others who have joint and several liability However, only the registered owner of a ship over 1,000 gross tonnage is required to provide financial security. The regulation of mutual liability is left to national law. Article 6 provides that the ship owner may limit liability "under any applicable national or international regime", such as the 1976 Convention on Limitation of Liability for Maritime Claims. ${ }^{57}$ Under this Convention, the limits of liability are on a sliding scale depending on the size of the ship. A 1996 protocol, not in force in 2006, will raise the limits. In any case, the reference to national and international law means a lack of uniformity in liability limits for oil spills from non-tanker vessels. While it was proposed to exclude from liability any person taking reasonable measures to prevent or minimize the effects of oil pollution, no agreement was reached to include such

\footnotetext{
56 See International Oil Pollution Compensation Fund, Annual Report for 2000, 37-40.

5716 ILM 606 (1977).
} 
a provision. Instead, the conference recommended legal provisions for such persons in domestic laws. ${ }^{58}$

For land-based activities, a Protocol on Liability and Compensation for Damage resulting from Transboundary Movements of Hazardous Wastes and their Disposal ${ }^{59}$ has further developed the regime of civil liability for environmental damage. Its purpose is to provide a comprehensive regime for liability and for adequate and prompt compensation for damage resulting from transboundary waste movements, including illegal traffic. It defines damage broadly to include loss of income directly deriving from an economic interest in any use of the environment, when that loss is incurred as a result of impairment of the environment. Compensation extends to the cost of measures of reinstatement of the impaired environment, limited to the costs of measures actually taken or to be undertaken and the costs of preventive measures, including any loss or damage caused by such measures. Preventive measures are defined as any reasonable measures taken by any person in response to an incident to prevent, minimize, or mitigate loss or damage, or to affect environmental clean-up. The Protocol applies to damage due to an incident occurring during a transboundary movement of hazardous wastes and other wastes and their disposal, including illegal traffic, in particular in relation to movements destined for disposal operations specified in Annex IV of the 1989 Basel Convention (art. 3). The Basel Protocol imposes strict liability on, first, the person who provides notification of a proposed transboundary movement according to article 6 of the Basel Convention, and, thereafter, the disposer of the wastes. Liability for damage is subject to financial limits specified in article 12(1) and Annex B to the Protocol. During the ten year period of liability, those potentially liable shall establish and maintain insurance or other financial guarantees. Liability limits are removed if the responsible person causes or contributes to causing damage by failure to comply with the provisions implementing the Basel Convention, or due to wrongful intentional, reckless or negligent acts or omissions.

The Protocol imposes upon the Contracting Parties the obligation to adopt the legislative, regulatory and administrative measures necessary to implement the Protocol and to inform the Secretariat of the Protocol of the measures it has taken. For the rest, the Protocol shall not affect the rights and obligations of the Contracting Parties under the rules of general international law with respect to State responsibility. The competent jurisdictions are the courts of the State where the damage was suffered or the incident occurred or the defendant has his habitual residence or has his principal place of business. All matters of substance or procedure regarding claims before the competent court shall be

58 See IMO Resolution on the Protection of Persons Taking Measures to Prevent or Minimize the Effects of Oil Pollution, IMO Doc. LEG/CONF.12/18.

59 Basel, 10 December 1999. 
governed by the law of that court. Enforceable judgments thus handed down shall be mutually recognized and enforced.

A regional model for comprehensive civil liability is the Lugano Convention on Civil Liability for Damages Resulting from the Exercise of Activities Dangerous for the Environment. ${ }^{60}$ It establishes general standards for indemnification of those injured by hazardous activities and products. The Convention broadly imposes responsibility on all persons and companies and State and all agencies exercising control over dangerous activities, irrespective of the place of the harm. However, if the damage occurs in a non-contracting State, the Convention permits reservations to be filed demanding reciprocity of remedies.

The Convention applies to dangerous activities and substances, including living modified organisms. The quality of dangerousness is largely based upon assessment of the risk of harm to man, the environment or property. Nuclear damage is excluded if the incident is regulated by the Paris Convention on Civil Liability of 1960 or by the Vienna Convention of 1963 with its amendments, or by national legislation at least as favorable to the plaintiffs as the Conventions. Workplace accidents covered by social security and automobile accidents in places inaccessible to the public as well as assimilated to other activities within the installation also are excluded.

In addition to compensation for death, bodily harm, and injury to property other than that found on the site or within the installation where the dangerous activity has taken place, recovery can be had for environmental harm, ${ }^{61}$ limited to the costs of reasonable measures taken to restore or rehabilitate the environment to its prior State. Recovery is also possible for the costs of mitigating measures and any losses or damage caused by such measures after an incident or event. The maximum amount of liability may be fixed by local law, which should also insist upon adequate insurance coverage taking into account the risks associated with the activity.

Anyone who is in control of a dangerous activity is responsible for damages caused by that activity. ${ }^{62}$ The problem of multiple or long-term sources is solved imposing joint responsibility and by placing the burden of proof on the various persons who were in control of the activity or activities to prove they were not responsible. In cases where the activity has ceased when the damage occurs, the

6021 June 1993, 32 ILM 1228 (1993).

61 For these purposes, environment is broadly defined to include biotic and abiotic natural resources, such as air, water, soil, fauna and flora, the interaction between them, cultural property and characteristic aspects of the countryside.

62 States parties may reserve to the basic principle of liability, to the extent of allowing the defendant to escape liability if it can show that the state of scientific and technical knowledge at the moment of the incident was insufficient to indicate the dangerous properties of the substance or the organism. 
last person in control will be liable unless he can show that the causative event took place before he was in control.

Liability is not imposed if damage occurs as a result of armed conflict, a natural disaster, an intentional act of a third party, a State command, "pollution of a level acceptable having regard to the relevant local circumstances", or if the activity was taken for the benefit of the person damaged, to the extent it was reasonable for the latter to be exposed to the risks of the dangerous activity, or if the injured party was at fault.

From the perspective of the plaintiff, there are several favorable provisions. Article 10 provides that in examining the proof of causality, a judge in any case falling within the terms of the Convention should take into account the probable risk of damage inherent in the dangerous activity in question. Moreover, the time limits for claims are rather long. According to article 18, actions should be brought within five years of the date on which the plaintiff knew or reasonably should have known of the damage and of the identity of the person in control. No action may be brought more than 30 years after the causative event or the last in a series of causative events. For waste disposal sites, the final date is 30 years from the closure of the site. Forum selection is also made possible: article 20 permits the action to be filed either in the courts of a State party where the damage occurred, where the dangerous activity took place, or where the defendant has its permanent residence.

Injunctive relief may be sought by environmental associations in the courts where the dangerous activity takes place, on conditions set by internal law. States may declare at signature, ratification, or accession that this possibility will be open to non-governmental organizations based in other States parties. Environmental groups may demand prohibition of any illegal dangerous activity threatening serious environmental harm as well as injunctions against the person in control of a dangerous activity, in order to require preventive or remedial actions be taken. Where remedial action is sought, the courts of the State where the action should be taken also have jurisdiction over the case. Public authorities have the right to intervene when environmental groups bring actions. Article 19 is explicitly subject to reservations.

All judgments rendered by a tribunal with jurisdiction according to the Convention are entitled to be recognized in other States parties unless they are contrary to public order, the defendant was not properly notified of the action in time to prepare a defense, or if the decision is irreconcilable with a decision rendered between the same parties (res judicata).

Finally, the Protocol on Civil Liability and Compensation for Damage Caused by the Transboundary Effects of Industrial Accidents on Transboundary Waters was formally adopted and signed by 22 countries at the Ministerial Conference "Environment for Europe" in Kiev, Ukraine, on 21 May 2003. It is a Joint Protocol to the 1992 Convention on the Protection and Use of Transboundary 
Watercourses and International Lakes and to the 1992 Convention on the Transboundary Effects of Industrial Accidents.

The Protocol gives individuals affected by the transboundary impact of industrial accidents on international watercourses a legal claim for adequate and prompt compensation. Companies will be liable for accidents at industrial installations, including tailing dams, as well as during transport via pipelines. Physical damage, damage to property, loss of income, the cost of reinstatement and response measures are covered by the Protocol. The Protocol sets financial limits of liability depending on the risk of the activity, i.e. the quantities of the hazardous substances that are or may be present and their toxicity or the risk they pose to the environment. To cover this liability, companies will have to establish financial securities, such as insurance or other guarantees. The Protocol establishes a principle of non-discrimination among victims: victims of the transboundary effects cannot be treated less favorably than victims from the country where the accident has occurred.

In sum, several common traits are found in the liability agreements:

(a) Identification of the polluter is assured through a presumption which channels responsibility. Thus, in case of damage, the responsibility automatically is imputed to the exploiter or the ship owner.

(b) The system of liability is settled by imposing strict liability for damage, but specifying a limited set of excuses.

(c) Jurisdictional competence is determined by designating the proper forum, in some cases that of the plaintiff, in other cases that of the polluter or in permitting the victim the free choice of tribunal.

(d) Time limits are imposed. The Lugano Convention makes it three years from the date of knowledge or the time when the plaintiff reasonably should have known of the damage and the identity of the operator. An absolute bar to suit is imposed after thirty years.

(e) Liability limits are coupled with mandatory insurance requirements.

(f) The execution of judgments is assured.

It must be noted, in conclusion, that some of the eleven major liability treaties are not in force, because many States oppose the limits on liability that these agreements contain. The Lugano Convention has not been ratified by any State as of October 2006. The HNS Convention has only 8 parties, the Bunker Oil Convention has 11 ratifications, and the Nuclear Carriage Convention has 17 parties. The 1992 Amended Convention on Civil Liability for Oil Pollution, the most widely accepted Convention, has 114 parties, followed by the 1992 Amended Fund Agreement which has 98 adherents. The fact of holdout States in turn discourages others from accepting what becomes an unequal burden-sharing. 
Limited liability originated in maritime law, in recognition of the value of maritime transport and the hazards of shipping, but some see it today as an unwarranted subsidy at the expense of other interests and as undermining the polluter pays principle. ${ }^{63}$ Those favoring limited liability respond that unlimited damage awards could drive responsible shipowners out of business. ${ }^{64}$ It is also argued that unlimited liability will make maritime transport uninsurable. In fact, liability limits have been set in large part according to insurance industry indications, rather than degree of risk and needs of victims. The problems are political and practical rather than principled.

\section{Conclusion}

As a rule, strict liability is linked with hazardous activities and States draft laws or regulations to identify such activities. States appear hesitant to accept international rules that would oblige them to restrict or accept liability for activities whose harmful environmental consequences are likely to be limited to their own territory; in this respect economic interests play a major political role. There are specific activities, however, which present a significant risk for the environment of the commons or of other States. Environmental damage from nuclear activities and marine pollution, in particular, may escape the territorial limits of States and cause transboundary damage to persons and/or to the environment. While international law has been slow in placing the risk of loss on the actor profiting from the enterprise, economic globalization potentially could lead to progress by harmonizing the conditions of operation in certain fields of activities dangerous to human health and to the environment.

63 See G. Gauci, "Limitation of Liability in Maritime Law: An Anachronism?”, 19 Marine Policy 65 (1995).

64 See R.R. Churchill, "Facilitating (Transnational) Civil Liability Litigation for Environmental Damage by Means of Treaties: Problems and Progress", 12 YB Int'l Envtl. L. 3, 35-36 (2001). 